\title{
レニンーアンジオテンシン系阻害薬の腎保護メカニズム
}

西山成

\section{Mechanisms Responsible for Renoprotective Effects of Renin-Angiotensin Inhibitors}

\author{
Akira Nishiyama \\ Department of Pharmacology, Kagawa University Medical School; 1750-1 Ikenobe, \\ Miki-cho, Kita-gun, Kagawa 761-0793, Japan.
}

(Received November 4, 2011)

\begin{abstract}
In recent years, the focus of interest on the role of the renin-angiotensin system (RAS) in the pathophysiology of hypertension and organ injury has changed to a major emphasis on the role of the local RAS in specific tissues. In the kidney, all of the RAS components are present and intrarenal angiotensin II (Ang II) is formed by independent multiple mechanisms. Ang II is compartmentalized in the renal interstitial fluid and the proximal tubular compartments with much higher concentrations than those existing in the circulation. It has also been revealed that inappropriate activation of the intrarenal RAS is an important contributor to the pathogenesis of chronic kidney disease (CKD). Indeed, most national guideline groups now recommend the use of RAS inhibitors in preference to other antihypertensive agents for hypertensive patients with CKD. In this review, we will briefly summarize our current understanding of independent regulation of the intrarenal RAS. We will also discuss the impact of RAS inhibitors in preventing the progressive increases in the intrarenal RAS during the development of CKD.
\end{abstract}

Key words — - angioitensin II (Ang II); angiotensin II $\mathrm{AT}_{1}$ receptor blocker (ARB); aldosterone; mineralocorticoid receptor (MR)

\section{はじめに}

大規模臨床試験により，降圧薬による血圧の厳格 なコントロールが慢性腎臟病（CKD）の進展の抑 制に重要であることが証明されている。JSH2009 で定められている降圧目標值は, $130 / 80 \mathrm{mmHg}$ 未 満とされ，尿タンパクが $1 \mathrm{~g} /$ 日以上であれば $125 /$ $75 \mathrm{mmHg}$ 未満である。さらに，CKD 患者に対し て，レニンーアンジオテンシン系（RAS）を阻害す る降圧薬であるアンジオテンシン変換酵素阻害薬 (ACEI) やアンジオテンシン $\mathrm{II} \mathrm{AT}_{1}$ 受容体遮断薬 （ARB）を使用すると，他の種類の降圧薬と比較し て，タンパク尿を減少させる又は腎機能の低下速度 を遅らせることが証明されている。このような臨床 エビデンスにより，JSH2009 では CKD 合併高血圧 症患者に対して RAS 阻害薬を第一選択薬として,

香川大学医学部薬理学（干761-0793 香川県木田郡三木 町大字池戸 1750-1)

e-mail: akira@kms.ac.jp

本総説は, 日本薬学会第 131 年会シンポジウム S 37 で 発表したものを中心に記述したものである.
厳格に血圧をコントロールすることが推奨されてい る。一方，ACEIやARBでは十分にタンパク尿が 減少しない症例に対して，アルドステロンの鉱質コ ルチコイド受容体（MR）における拮抗薬が著効を 示す報告も多く，高カリウム血症に注意しながら投 与するケースが増えている，さらに最近では，直接 的レニン阻害薬を ARB と併用すると，降圧を介さ ずにタンパク尿が減少することも報告された.

臟器内アンジオテンシン II は様々な細胞障害作 用を局所で生じ，臟器障害に直結することが明らか となってきている。腎臓も例外ではなく，腎組織内 アンジオテンシン II 濃度の上昇が慢性腎臟病 （CKD）の発症・進展に対して密接に関与している と考えられている. RAS は循環血漿中と腎臓内局 所では全く異なつた調節を受けており，アンジオテ ンシン II は腎臓組織では血漿中よりも高い濃度で 存在している.しかも, 腎内の部位によってもアン ジオテンシン II 濃度は一律ではなく, 特に間質や 原尿中では血漿中の数十倍にも及ぶ高い濃度でアン ジオテンシン II は存在している。腎臟内 RAS の調 
節機構については古くから数多くの研究が行われて いるが，最近になっても次々と新しいアンジオテン シン II の産生経路，並びに病態への関与が明らか となってきている。ここでは，腎蔵内局所 RAS の 独自の活性化機構と病態への関与について最近の知 見を含めて紹介し，RAS 阻害薬を使用した CKD 患者の治療における，腎内局所 RAS 抑制作用の重 要性について考察する.

1. 腎内アンジオテンシン II 産生機構と, それ に対する RAS 阻害薬の作用

腎臓では，アンジオテンシン II が $\mathrm{AT}_{1}$ 受容体に 結合し，様々な細胞内情報伝達シグナルの活性化を 介して，局所で発現しているアンジオテンシン II の基質であるアンジオテンシノーゲンの発現を充進 させる. ${ }^{1,2)}$ また，血中のアンジオテンシン II が腎 臓へ到達すると, $\mathrm{AT}_{1}$ 受容体とともに近位尿細管 細胞の endosome へ活発に取り込まれる. ${ }^{3)} さ ら$ に，アンジオテンシン II は $\mathrm{AT}_{1}$ 受容体を介して傍 糸球体細胞からの（プロ）レニンの産生・分泌に対 してネガティブ・フィードバック調節をしている が，集合尿細管での（プロ）レニン発現に対しては 全く逆の現象が生じる.4) すなわち，腎臓ではいっ たんアンジオテンシン II が産生されると，さらに RAS 活性が上昇し，さらなるアンジオテンシン II の産生につながるといつた悪循環が形成される可能 性がある (Fig. 1)。これら腎内 RAS コンポーネン トのうち，われわれは特にアンジオテンシノーゲン が腎臓局所でのアンジオテンシン II の産生調節に 重要な役割を果たしていると考えている。これにつ いて現在われわれは，様々な病態の CKD 患者にて 尿中アンジオテンシノーゲンを測定することによ り，腎内 RAS 活性の評価を試みている (後述).

一方，これらの腎臟におけるアンジオテンシン II 産生の悪循環は，ARB 投与により完全に阻害さ れる。すなわち，ARB は血漿中アンジオテンシン II 濃度を上昇させるものの，腎蔵においては $\mathrm{AT}_{1}$ 受容体を介した様々な生体反応を阻害するの夕なら ず，アンジオテンシン II の産生自体も減少させる のである。ここで重要なポイントは，ARB 投与に より細胞内のアンジオテンシン II レベルが減少す ることは，細胞膜に存在している $\mathrm{AT}_{1}$ 受容体の遮 断とは異なった作用をもたらす可能性があるという ことである，最近， $\mathrm{AT}_{1}$ 受容体は細胞質や核膜に

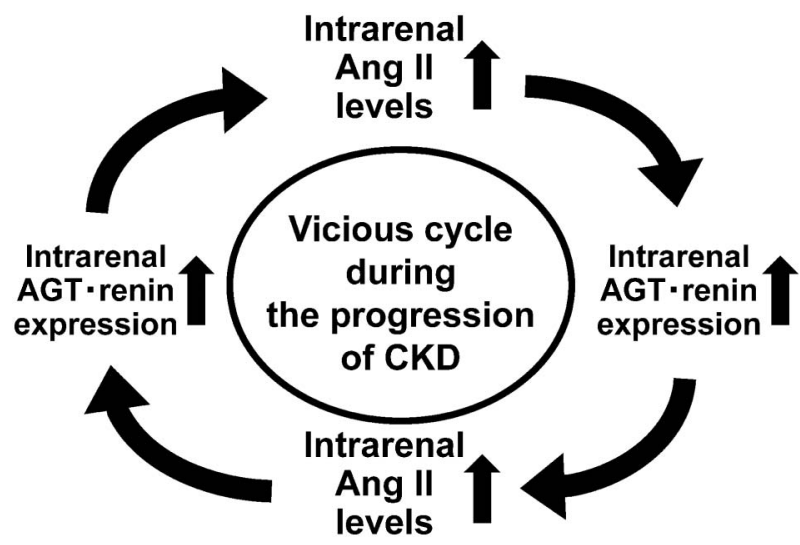

Fig. 1. Vicious Cycle of Intrarenal RAS Augmentation during the Progression of CKD

$\mathrm{RAS}=$ renin-angiotensin-system. AGT $=$ angiotensinogen. Ang $\mathrm{II}=$ angiotensin II.

も存在していると言われており，アンジオテンシン II による様々な作用を司っていると考えられてい る.5) ところが，生体に投与された ARB の大部分 がアルブミンに結合することが知られており，細胞 内に十分入り込んで内部の $\mathrm{AT}_{1}$ 受容体作用をブロ ックしているのかについては明らかではない.した がって，臨床で観察されるような強い腎保護作用は,

ARB の腎細胞内アンジオテンシン II 減少作用によ って発揮されている可能性も考えられる。一方で最 近，キマーゼ6)や（プロ）レニン受容体7)などを介 する全く新しいコンセプトの腎内アンジオテンシン II 産生経路が次々と発見されている。詳細は他著 に譲るが，これらはいずれも，CKDにおける腎組 織内アンジテンシン II 産生の克進に密接に係わっ ていることが動物実験にて証明されている。なお， 筆者らは，最近のデー夕に基づき，ACEIによって もたらされる腎保護作用は, 腎内アンジオテンシン II 産生の抑制作用によるものがメインではないと 推測している（2009 年米国心臓財団 High Blood Pressure Council にて発表).

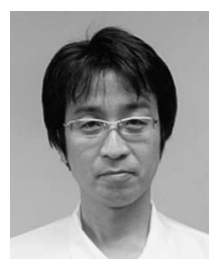

西山 成
香川大学医学部薬理学教授 (http://www. $\mathrm{kms} . \mathrm{ac} . \mathrm{jp} /$ ～yakuri/). 1993 年香川医 科大学卒業. 2007 年より現職, 2009 年 より香川大学医学部附属病院先端医療 センター・副センター長, 2010 年より 同糖尿病センター・副センター長, 2011 年より香川大学動物実験施設長を 兼任. 


\section{CKD における腎内アンジオテンシン II}

ACEI・ARB は強い腎保護作用を示すが，かなら ずしも降圧作用に依存しない. ${ }^{1)}$ 食塩感受性ラット に食塩を過剩投与すると，血漿レニン活性（PRA） と血漿中アンジオテンシン II 濃度は著明に低下す るが，腎組織ではアンジオテンシノーゲンの異常な 発現六進に伴って，アンジオテンシン II 濃度は低 下せずにむしろ上昇する. ${ }^{8)}$ このように，実際の診 療で PRA の低下を認める CKD 患者でも, 腎組織 RAS はむしろ活性化されているケースが多く存在 するものと考えられる。このような病態では血漿中 アンジオテンシン II 濃度が低いため, ACEI・ ARB の降圧作用が弱いケースも多いが，腎保護効 果には強い期待が持てる。このほかにも，本態性高 血圧ラット9) や糖尿病モデルラット10)など，従来は 低レニン型と言われてきた病態モデルにおいても,

実際には腎組織局所のアンジオテンシン II 濃度が 上昇しており，ACEI・ARBが降圧を超えて腎保護 効果を示す。いずれのモデルにおいても PRA ある いは血漿中アンジオテンシン II 濃度はかならずし も上昇しておらず，臨床的に同様の病態では注意深 い観察が必要となる。山本ら ${ }^{11)}$ は，尿にリコンビナ ント・ヒトレニンを加えて産生されたアンジオテン シン I をラジオイムノアッセイ法にて測定すること により，尿中アンジオテンシノーゲンを評価し，こ の排泄が CKD 患者で上昇していることを報告して いる．最近では，アンジオテンシノーゲンの ELISA 測定キットも販売されており，CKD 患者で RAS 活性が上昇していることが証明されてい る. ${ }^{12,13)}$

\section{3. アルドステロンと CKD}

アルドステロンが尿細管でのナトリウム再吸収を 克進して高血圧を生じることは，古くより知られて いる．最近では，アルドステロンがその他の機序に より高血圧を生じることが実験的に示唆されている が，詳細は他著に譲る。一方，アルドステロンの CKD における役割については，最近ようやく明ら かとなってきた.アルドステロンは主に副腎で産生 されるが, 糖尿病ラットの糸球体ではアルドステロ ンの合成酵素である CYP11B2 の発現が増加してい

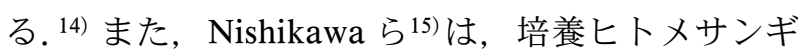
ウム細胞にコレステロールとアンジオテンシン II を加えるとアルドステロンが培養液中に遊離される
ことを証明した。したがって，病態によっては腎内 局所でアルドステロンが活発に産生され，病態進展 に関与している可能性が考えられる。一方，循環血 液中のアルドステロンが心臓組織に取り込まれる可 能性が示唆されているが，腎組織での検討は行われ ていない.

ラットにアルドステロンと食塩を慢性投与する と，腎糸球体上皮障害と重度タンパク尿を生じる。 また，糸球体の肥大・細胞数の増加・メサンギウム 領域の拡大，あるいは尿細管間質障害などが観察さ

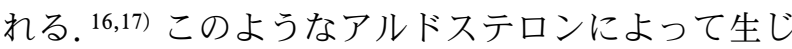
る腎障害は，選択的 MR 拮抗薬であるエプレレノ ンの投与によって完全に阻害されることから，アル ドステロンによって生じる腎障害は MR を介して いると考えられる. ${ }^{16)}$ 実際，MRが培養メサンギウ ム細胞・ポドサイト・腎線維芽細胞などに遺伝子あ るいはタンパクレベルで強く発現していることが確 認されており, 18-21) それぞれの腎臓の部位の MR に アルドステロンが作用して，CKD 発症・進展に関 与していると考えられている (Fig. 2)。最近では,

腎臟でのアルドステロンを介さない MR 刺激作用 による CKD の発症が細胞・動物レベルで報告され ており, ${ }^{22,23)}$ 今後の詳細な検討が望まれている。

一方, 臨床でも原発性アルドステロン症患者では タンパク尿が多く観察されることが指摘されていた が, 24) 腎症患者では血中アルドステロン濃度とタン パク尿の程度が有意に相関することが報告されてい る. ${ }^{25)}$ さらに，重度タンパク尿を生じている腎症患 者では，血中アルドステロン濃度がクレアチニンク リアランスの低下あるいは腎障害スコアと有意に相 関していることが報告された。 ${ }^{26)} し か も ，$ 腎症患者 では腎組織中 MR 発現が増加していることも示さ れている. ${ }^{26)} \mathrm{MR}$ 拮抗薬の腎保護作用に関する臨床 報告も既に多く行われている，RAS 阻害薬を服用 している CKD 患者に対して MR 拮抗薬を併用する と，血圧には影響を与えないもののタンパク尿の有 意な減少を認める. ${ }^{27-29)}$ 現在までのところ, 高カリ ウム血症が懸念されて MR 拮抗薬の CKD への適応 は積極的には推奨されていないが，実際に腎保護作 用を示すことは間違いない。

おわりに

以上, 腎内局所 RAS 制御機構や CKD の病態に おけるアルドステロンの役割などについて概説し 


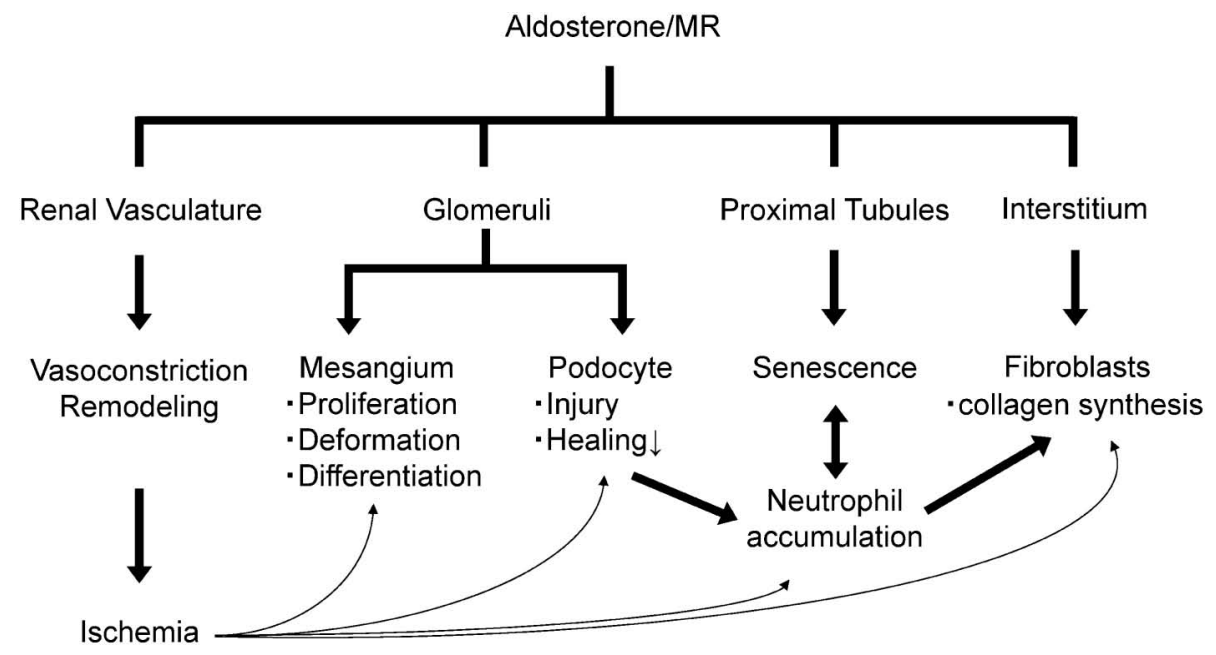

Fig. 2. Possible Mechanisms Responsible for Aldosterone/MR-dependent Renal Injury $\mathrm{MR}=$ mineralocorticoid receptor .

た. 腎内局所 RAS の制御機構や働きに関しては,

いまだ新しい知見が続々と報告されており，その完 全解明にはさらなる研究努力が必要であると思われ る. 今後，さらに検討を重ねていくことによって， 新しい治療戦略が確立されることが期待される。

\section{REFERENCES}

1) Kobori H., Nangaku M., Navar L. G., Nishiyama A., Pharmacol. Rev., 59, 251-287 (2007).

2) Kobori H., Prieto-Carrasquero M. C., Ozawa Y., Navar L. G., Hypertension, 43, 1126-1132 (2004).

3) Zhuo J. L., Imig J. D., Hammond T. G., Orengo S., Benes E., Navar L. G., Hypertension, 39, 116-121 (2002).

4) Prieto-Carrasquero M. C., Kobori H., Ozawa Y., Gutiérrez A., Seth D., Navar L. G., Am. J. Physiol. Renal Physiol., 289, F632-F637 (2005).

5) Li X. C., Zhuo J. L., Am. J. Physiol. Cell Physiol., 294, C1034-C1045 (2008).

6) Fan Y. Y., Nishiyama A., Fujisawa Y., Kobori H., Nakano D., Matsuura J., Hase N., Hitomi H., Kiyomoto H., Urata H., Kohno M., J. Pharmacol. Sci., 111, 82-90 (2008) .

7) Ichihara A., Hayashi M., Kaneshiro Y., Suzuki F., Nakagawa T., Tada Y., Koura Y., Nishiyama A., Okada H., Uddin M. N., Nabi A. H., Ishida Y., Inagami T., Saruta T., J.
Clin. Invest., 114, 1128-1135 (2004).

8) Kobori H., Nishiyama A., Abe Y., Navar L. G., Hypertension, 41, 592-597 (2003).

9) Kobori H., Ozawa Y., Suzaki Y., Nishiyama A., J. Am. Soc. Nephrol., 16, 2073-2080 (2005).

10) Nagai Y., Yao L., Kobori H., Miyata K., Ozawa Y., Miyatake A., Yukimura T., Shokoji T., Kimura S., Kiyomoto H., Kohno M., Abe Y., Nishiyama A., J. Am. Soc. Nephrol., 16, 703-711 (2005).

11) Yamamoto T., Nakagawa T., Suzuki H., Ohashi N., Fukasawa H., Fujigaki Y., Kato A., Nakamura Y., Suzuki F., Hishida A., J. Am. Soc. Nephrol., 18, 1558-1565 (2007).

12) Nishiyama A., Konishi Y., Ohashi N., Morikawa T., Urushihara M., Maeda I., Hamada M., Kishida M., Hitomi H., Shirahashi N., Kobori H., Imanishi M., Nephrol. Dial. Transplant., 26, 170-177 (2011).

13) Ogawa S., Kobori H., Ohashi N., Urushihara M., Nishiyama A., Mori T., Ishizuka T., Nako K., Ito S., Biomark Insights, 4, 97-102 (2009).

14) Xue C., Siragy H. M., Hypertension, 46, 584590 (2005).

15) Nishikawa T., Suematsu S., Saito J., Soyama A., Ito H., Kino T., Chrousos G., J. Steroid Biochem. Mol. Biol., 96, 309-316 (2005).

16) Nishiyama A., Yao L., Nagai Y., Miyata K., Yoshizumi M., Kagami S., Kondo S., Kiyo- 
moto H., Shokoji T., Kimura S., Kohno M., Abe Y., Hypertension, 43, 841-848 (2004).

17) Sun G. P., Kohno M., Guo P., Nagai Y., Miyata K., Fan Y. Y., Kimura S., Kiyomoto H., Ohmori K., Li D. T., Abe Y., Nishiyama A., J. Am. Soc. Nephrol., 17, 2193-2201 (2006).

18) Rafiq K., Hitomi H., Nakano D., Nishiyama A., J. Pharmacol. Sci., 115, 1-7 (2011) .

19) Nishiyama A., Yao L., Fan Y., Kyaw M., Kataoka N., Hashimoto K., Nagai Y., Nakamura E., Yoshizumi M., Shokoji T., Kimura S., Kiyomoto H., Tsujioka K., Kohno M., Tamaki T., Kajiya F., Abe Y., Hypertension, 45, 710-716 (2005).

20) Nagai Y., Miyata K., Sun G. P., Rahman M., Kimura S., Miyatake A., Kiyomoto H., Kohno M., Abe Y., Yoshizumi M., Nishiyama A., Hypertension, 46, 1039-1045 (2005) .

21) Kiyomoto H., Rafiq K., Mostofa M., Nishiyama A., J. Pharmacol. Sci., 108, 399-405 (2008).

22) Shibata S., Nagase M., Yoshida S., Kawa- razaki W., Kurihara H., Tanaka H., Miyoshi J., Takai Y., Fujita T., Nat. Med., 14, 13701376 (2008).

23) Liu G., Miyata K., Hitomi H., Yao L., Sun G. P., Suzaki Y., Hosomi N., Kiyomoto H., Nakano D., Tamaki T., Yoshizumi M., Nishiyama A., J. Hypertens., 28, 536-542 (2010).

24) Nishimura M., Uzu T., Fujii T., Kuroda S., Nakamura S., Inenaga T., Kimura G., Am. J. Kidney Dis., 33, 261-266 (1999).

25) Bianchi S., Bigazzi R., Campese V. M., Am. J. Kidney Dis., 46, 45-51 (2005).

26) Quinkler M., Zehnder D., Eardley K. S., Lepenies J., Howie A. J., Hughes S. V., Cockwell P., Hewison M., Stewart P. M., Circulation, 112, 1435-1443 (2005).

27) Chrysostomou A., Becker G., N. Engl. J. Med., 345, 925-926 (2001).

28) Sato A., Hayashi K., Naruse M., Saruta T., Hypertension, 41, 64-68 (2003).

29) Mehdi U. F., Adams-Huet B., Raskin P., Vega G. L., Toto R. D., J. Am. Soc. Nephrol., 20, 2641-2650 (2009). 